\title{
PERKEMBANGAN TEOLOGI ISLAM KLASIK DAN MODERN
}

\author{
Udung Hari Darifah ${ }^{1}$, Nurwadjah Ahmad², Andewi Suhartini ${ }^{3}$ \\ 1,2,3Universitas Sunan Gunung Djati Bandung, Indonesia \\ e-mail:(udunghari8@iaid.ac.id)
}

\begin{abstract}
The development of Islamic theology from time to time always experiences ups and downs. After the death of the Apostle, the main area of theological systematic reflection comes from the most authoritative sources, namely the Qur'an and Hadith, because they are the most important jurisprudence (figh). This research method uses a qualitative approach. The object under study is the development of classical and modern Islamic theology. Collecting data through the library method (search library) through the explanation of books that support the explanation of the development of classical and modern Islamic theology. Classical Islamic thought is a very valuable legacy to help solve increasingly acute contemporary problems. Therefore, studying and taking the treasures of classical Islamic thought must be done even in a very modern world. But taking the inheritance must still be accompanied by a critical-analytic attitude. Therefore, it is necessary to ground Islamic theology in the context of Islam in a modern country, so that it can convey about Islam in the public sphere but does not offend or threaten other religions there, most likely through dialogue between religions. Grounding Islamic theology in the context of modern life does require accurate strategies and methodologies.
\end{abstract}

Keywords: Systematic Theology, Classical Islamic Theology, Modern Theology, Al-Quran, Hadith

\begin{abstract}
ABSTRAK
Perkembangan teologi Islam dari waktu ke waktu senantiasa mengalami pasang surut. Sepeninggalan Rasul, area utama refleksi sistematis teologis bersumber pada sumber yang paling otoritatif yaitu Al-quran dan Hadis, karena keduanya merupakan yurisprudensi (fiqh) yang paling utama. Metode penelitian ini menggunakan pendekatan kualitatif. Objek yang diteliti adalah perkembangan teologi Islam klasik dan modern. Pengumpulan data melalui metode kepustakaan (search library) melalui penjelasan buku-buku yang menunjang penjelasan perkembangan teologi Islam klasik dan modern. Pemikiran Islam klasik merupakan warisan yang sangat berharga untuk membantu memecahkan problem kontemporer yang semakin akut. Oleh karena itu, mempelajari dan mengambil khazanah pemikiran Islam klasik harus dilakukan dalam dunia yang sangat modern sekalipun. Tetapi pengambilan warisan itu harus tetap disertai dengan sikap kritis-analitik. Karenanya diperlukan membumikan teologi islam dalam konteks islam pada negara modern, sehingga bisa menyampaikan mengenai Islam di ruang publik namun tidak menyinggung atau mengancam Agama lain disana, kemungkinan besar hal itu melalui dialog antar Agama. Membumikan teologi Islam dalam konteks kehidupan modern memang memerlukan strategi dan metodologi yang akurat.
\end{abstract}

Kata kunci: Sistematis Teologi, Teologi Islam Klasik, Teologi Modern, Al-Quran, Hadist

Cara sitasi: Darifah, U.H., Ahmad, N., \& Suhartini, A. (2021). Perkembangan Teologi Islam Klasik dan Modern. J-KIP (Jurnal Keguruan dan IImu Pendidikan), 2 (3), 265-274. 


\section{PENDAHULUAN}

Pemikiran Islam merupakan hasil perpaduan antara normatifitas dengan historisitas. Pemikiran keagamaan Islam (dari para pemikir muslim baik individu atau kelompok) merupakan hasil usaha intelektual muslim dalam mempertemukan wahyu (sebagai sumber ajaran Islam) dengan situasi dan kondisi tertentu atau perkembangan sejarah dalam kurun waktu tertentu. Dalam kajian yang lebih lanjut, telah dilakukan upaya bagaimana mengambil relevansi dan sumbangan serta kesinambungan intelektualisme masa lalu untuk dikaitkan dengan problem kaum muslim saat ini. Dapat dikatakan bahwa pemikiran keagamaan Islam serta konsep yang terkait di dalamnya tidak bisa dilepaskan sama sekali dari perubahan sejarah yang mengitarinya

Perkembangan teologi Islam dari waktu ke waktu senantiasa mengalami pasang surut, sesuai dengan tingkat perkembangan para ilmuan menganalisa ajaran-ajaran teologi dalam Islam, karena beberapa ilmuan terdahulu menelaah teologi dengan cara pandang statis dan fatalisme, sehingga menyebabkan berkembangnya cara pandang yang stagnan dan pasif, sedangkan perkembangan sosial kemasyarakatan, mengalami kompetisi yang tiada hentinya dari waktu ke waktu, sehingga sangat dibutuhkan cara pandang teologi aktual dan mampu menjawab berbagai tantangan zaman modern.

Teologi menurut Hombi berasal dari bahasa Inggris, theos yang berarti Tuhan, dan logos yang berarti ilmu atau wacana. Dalam bahasa Yunani oleh Bagus Theologia mempunyai beberapa pengertian, yakni ilmu tentang hubungan dunia ilahi dengan dunia fisik, tentang hakikat dan kehendak Tuhan, doktrin atau keyakinan tentang Tuhan, dan usaha yang sistematis untuk meyakinkan, menafsirkan dan membenarkan secara konsisten keyakinan tentang Tuhan.

Hanafi (1989) menjelaskan dalam pengantarnya, bahwa teologi memiliki banyak dimensi pengertian, namun secara umum teologi ialah "the science which treats of the facts and phenomena of religion, and the relations between God and man", atau ilmu yang membicarakan kenyataankenyataan dan gejala-gejala agama dan membicarakan hubungan Tuhan dan manusia baik dengan jalan penyelidikan maupun pemikiran murni, atau dengan jalan wahyu.

Menurut Wiliam Resse dalam Abdur Razak \& Anwar (2006) teologi berasal dari bahasa Inggris yaitu theology yang artinya discours or reason concerning God (diskursus atau pemikiran tentang Tuhan) dengan kata ini Reese lebih jauh mengatakan "teologi merupakan disiplin ilmu yang berbicara tentang kebenaran wahyu serta independensi filsafat ilmu pengetahuan", dan Gove mengatakan bahwa "teologi merupakan penjelasan tentang keimanan, perbuatan dan pengalaman agama secara rasional".

Selain itu diketahui bahwa teologi merupakan suatu disiplin ilmu yang membahas mengenai Ketuhanan, yaitu membicarakan dzat Tuhan dari segala seginya dan hubungannya dengan alam. Karena itu teologi biasanya diikuti dengan kualifikasi tertentu seperti teologi Yahudi, teologi Kristen dan Teologi Islam (IImu kalam).

Dalam buku lain, Hanafi menjelaskan bahwa ruang lingkup pembahasan ilmu kalam tentang keyakinan bertuhan inilah yang juga dinamakan "teologi". Hanya saja karena ruang lingkup pembahasannya berdasarkan prinsip dasar ajaran agama, maka dinamakan teologi agama. Untuk itu, ilmu kalam yang memiliki dimensi bahasan tentang ketuhanan (keyakinan atau teologi), yang berdasarkan dan bersumber pada prinsip-prinsip ajaran agama islam maka dinamakan sebagai Teologi Islam. Perubahan dari ilmu kalam ke teologi Islam ini menurut Abdullah (1994) bahwasannya telah terjadi akulturasi dan inkulturasi (pergeseran pemikiran) keagamaan yang begitu jelas.

Sepeninggalan Rasul, area utama refleksi sistematis teologis bersumber pada sumber yang paling otoritatif adalah Al-quran dan Hadis, karena keduanya merupakan yurisprudensi (figh) yang paling utama. Masalah yang termasuk dalam kajian teologi "kalam" era modern di antaranya, Pertama masalah Islam dan kebebasan yang berkaitan dengan adanya prinsip persamaan dalam aspek perbuatan dan pemikiran. Kedua, masalah Islam dan keadilan ('adalah) yang di dalamnya membahas tentang reinterpretasi makna keadilan dan persamaan antar manusia dalam berbagai 
aspek. Ketiga, masalah hak-hak manusia yang berkaitan dengan hubungan antara agama dan hakhak manusia, sejauh mana hak-hak manusia tersebut dan bagaimana pengertian dalam ranah yang lebih global. Keempat, masalah yang berkaitan dengan perempuan yang bisa mencakup persamaaan dan keadilan bagi seorang perempuan dan bagaimana keadilan tersebut terbentuk. Kelima, permasalahan-permasalahan yang berkaitan dengan persoalan filsafat dan permasalahan kontemporer yang dibahas oleh kalangan orientalisme.

Dalam pemikiran Filsafat Islam, terdapat konsep penciptaan alam melalui Emanasi. Konsep ini merupakan pengaruh teori Emanasi Neoplatonisme dari Yunani yang mulai berkembang di dunia Islam. Dalam pemikiran Kalam, khususnya aliran Mu'tazilah, terdapat konsep tauhid. (mengesakan Tuhan). Konsep ini merupakan upaya kaum Mu'tazilah untuk mengesakan Tuhan secara murni dan sekaligus menghilangkan pengaruh paham sifatiyah atau jismiyah. Tuhan tidak memiliki sifat, la hanya Esa dalam dzat dan af'alNya. Paham sifatiyah atau jismiyah merupakan pengaruh filsafat Yunani yang menganggap bahwa dalam diri Tuhan melekat sifat-sifat seperti manusia. Sedangkan dalam Tasawuf terdapat konsep mahabbah (mendekati Tuhan dengan cinta). Konsep yang dipelopori oleh Rabi'ah al-Adawiyah ini merupakan hasil pergumulan antara ajaran Islam tentang cinta kepada Tuhan dengan realitas masyarakat pada akhir abad ke-2, di mana pada saat itu perkembangan figh hanya mengutamakan hal-hal yang bersifat lahiriah (eksoteris) dan mengabaikan dimensi Islam yang batiniah (esoteris). Perlu dicatat bahwa perkembangan figh tidak lepas dari pengaruh dari pandangan rasional-filosofis.

Implikasi dari uraian di atas bahwa produk pemikiran Islam, baik dalam Filsafat, Kalam, maupun Tasawuf (dan Fiqh), akan selalu berkembang sesuai dengan perkembangan sejarah, sehingga memungkinkan adanya perbedaan-perbedaan antara produk pemikiran Islam pada masa lalu (klasik) dengan produk pemikiran Islam pada masa kini dan nanti (kontemporer). Anshary (2005) mengelompokkan warisan Islam klasik ke dalam tiga figur, yaitu ulama, filosof, dan sufi. Ketiganya merupakan agen penting dalam perkembangan peradaban dan keilmuan Islam.

\section{METODE PENELITIAN}

Metode Penelitian ini menggunakan pendekatan kualitatif. Objek yang diteliti adalah perkembangan teologi Islam klasik dan Modern. Pengumpulan data melalui metode kepustakaan (search library) melalui buku-buku yang menunjang penjelasan perkembangan teologi Islam klasik dan modern.

\section{PEMBAHASAN}

\section{Ruang Lingkup Teologi Islam Klasik}

Ilmu kalam klasik adalah teologi Islam yang pokok pembahasannya lebih cenderung kepada pembahasan tentang Ketuhanan. Pembahasan pokok teologis yang terdapat dalam ilmu kalam klasik telah jauh menyimpang dari misinya yang paling awal dan mendasar, yaitu liberasi dan emansipasi umat manusia. Padahal semangat awal dan misi paling mendasar dari gagasan teologi Islam (tauhid) sebagaimana tercermin di masa Nabi SAW sangatlah liberatif, progresif, emansipatif, dan revolutif. IImu kalam menjadi suatu rangkaian kesatuan sejarah, dan telah ada di masa lampau, masa sekarang dan akan tetap ada di masa yang akan datang. Beberapa aliran yang akan diuraikan adalah Khawarij, Jabariyah, Qadariyah, Mu'tazilah, Ahlussunnah Waljamaah, Syiah.

\section{Ruang Lingkup Teologi Islam Modern}

Teologi modern merupakan ilmu yang mempelajari ajaran-ajaran dasar suatu agama. Dalam Islam khususnya, teologi disebut sebagai ilmu kalam. Secara umum teologi rasional maksudnya harus mempergunakan rasio dalam menyikapi masalah. Namun bukan berarti menyepelekan wahyu. Karena di dalam Al-Qur'an hanya memuat sebagian kecil ayat ketentuan-ketentuan tentang iman, ibadah, hidup bermasyarakat, serta hal-hal mengenai ilmu pengetahuan dan fenomena alam. 
Secara teologis Islam merupakan sistem nilai yang bersifat ilahiyah, tetapi dari sudut sosiologis, ia merupakan fenomena peradaban, kultural, dan realitas sosial dalam kehidupan manusia. la tidak dapat menghindarkan diri dari kenyataan sosial lain, yaitu perubahan.

Pandangan umat Islam terhadap modernitas barat dapat ditipologikan menjadi 3 (tiga) kelompok, yaitu modernis (ashraniyyun hadatsiyun), tradisionalis atau salafi (salafiyyun) dan kaum elektis (tadzabdzub). Yang pertama menganjurkan adopsi modernitas berat sebagai model yang tepat bagi masa kini. Artinya sebagai model secara historis memaksakan dirinya sebagai paradigma peradaban modern untuk masa kini dan masa depan. Sikap kaum salafi sebaliknya berupaya mengembalikan kejayaan Islam masa lalu sebelum terjadinya penyimpangan dan kemunduran. Sedangkan yang terakhir (kaum elektis) berupaya menghadapi unsur-unsur yang terbaik, baik yang terdapat dalam model barat modern maupun dalam Islam masa lalu, serta menyatukan diantara keduanya dalam bentuk yang dianggap memenuhi kedua model tersebut. Era modern secara umum dimulai ketika masyarakat Eropa menyadari tentang pentingnya kembali berfikir filsafat.

Para pemikir Eropa kembali bergelut dalam dunia ide yang dikembangkan dalam tataran praktis menjadi gerakan penciptaan alat-ala yang mampu memudahkan segala urusan manusia. Mereka menyebutnya dengan "moda" atau „modern". Era ini terjadi pada awal-awal abad ke-16, yang dikenal dengan istilah 'renaissance'. Sementara dalam Islam, bermula dari kesadaran umat Islam untuk bangkit dari keterpurukan pasca keruntuhan Bani Abbasiyah. Periode modern ini terjadi sejak tahun 1800-an hingga sekarang. Pada periode ini, muncul banyak tokoh yang menyerukan ide-ide sekaligus gerakan pembaharuan yang bermuatan visi peradaban Islam. Mereka ini merupakan para pendakwah rasional. Berbicara tentang corak pemikiran kalam modern, tentu saja akan sangat bervariasi, sesuai dengan situasi dan kondisi masyarakatnya. Pada masyarakat yang maju, barangkali pemikiran kalamnya cenderung ke arah rasional, yang mengharuskan segala sesuatu dapat bersifat logis dan empiris. Pada masyarakat berkembang, kemungkinan besar berada pada garis tengahnya. Sementara pada masyarakat tertinggal, pemikiran kalam akan cenderung mengarah pada konsep jabariyah yang pasrah pada segala sesuatu yang saat itu ada di hadapannya.

Hal ini dapat dilihat dari corak pemikiran kalam para tokoh muslim di abad modern, seperti Muhammad Abduh, Sayyid Ahmad Khan, Ismail Raji Al-Faruqi, Hasan Hanafi dan lain sebagainya. Masing-masing menunjukkan corak yang berbeda dalam memahami teks-teks agama, yang kemudian melahirkan paham kalamnya sendiri. Salah satu tokoh kunci yang namanya tak pernah luput dari perhatian adalah Muhammad Abduh, yang diperkenalkan oleh muridnya yang terkenal, yaitu Rasyid Ridha. Tokoh yang satu itu, juga banyak disorot terkait dengan pemikiran kalamnya. Ajaran Islam, yang kristalnya berupa Al-Qur'an dan sunnah Nabi, diyakini oleh umat Islam dapat mengantisipasi segala kemungkinan yang diproduksi oleh kurun zaman. Modernitas yang telah menjadi arus utama peradaban dunia di abad XIX dan seterusnya telah menawarkan berbagai janjijanji kebahagiaan. Namun dalam praktikya modernitas justru banyak menimbulkan persoalan baru. Peradaban modern justru banyak melakukan dehumanisasi kehidupan manusia itu sendiri. Dengan cita-cita kemajuan, peradaban modern banyak melakukan kerusakan dan bencana yang menyengsarakan orang banyak. Manusia hanya dipandang sebagai entitas fisik yang tak berdimensi spritual, maka peradaban modern justru menjadikan makhluk yang teralienasi, dilanda kebingungan dan kemapanan makna akibat modernisasi yang lepas dari dimensi spiritual, maka seperti yang dikatakan oleh Doni Gahral Adian, manusia dihadapkan pada kenyataan bahwa ia kehilangan kontrol atas hidupnya di mana ia terdeterminasi oleh hukum-hukum birokasi, mekanisme pasar, hukum, sejarah dan lain sebagainya.

Abbas (2005) mengatakan bahwa modernisme adalah aliran-aliran pemikir keagamaan yang menafsirkan Islam melalui pendekatan rasional untuk menyesuaikan dengan perkembangan zaman. Dengan demikian Islam harus beradaptasi dengan perubahan-perubahan yang terjadi di zaman modern Untuk itu, umat Islam harus kembali ke ajaran-ajaran Islam yang semula, ajaran-ajaran 
Islam seperti yang terdapat di zaman Salaf, yaitu zaman sahabat dan ulama-ulama besar, kemudian menyesuaikannya dengan keadaan modern sekarang.

Dalam rangka penyesuaian itu, Abduh mengambil rujukan kepada pemikiran Ibn Taimiyah yang membagi ajaran Islam ke dalam dua kategori: ibadah dan mu'amalah (hidup kemasyarakatan manusia). la melihat bahwa ajaran yang terdapat dalam Al-Qurean dan hadits mengenai ibadah bersifat tegas, jelas dan terperinci. Sebaliknya, ajaran-ajaran mengenai hidup kemasyarakatan umat Islam merupakan dasar-dasar dan prinsip-prinsip umum yang tidak terperinci dan sedikit jumlahnya. Karena prinsip-prinsip itu bersifat umum, tanpa perincian, maka semua itu dapat disesuaikan dengan tuntutan zaman. Memperhatikan pernyataan di atas, berarti teologi kontemporer orientasinya pada transformasi sosial masyarakat, melakukan langkah praktis karena perintah nash. Sedangkan aliran teologi klasik sebagaimana sering kita diskusikan, hanya berkutat pada persoalan hakikat yang berdasarkan atas penafsiran terhadap wahyu Allah dan Sunnah berhubungan dengan ketuhanan, keimanan, takdir, dosa, kafir, imamah, khalifah dan perbuatan-perbuatan manusia.

Aliran teologi Islam modern ini bisa saja orang memandang sebagai Islam kiri, Islam liberal, Islam progresif khazanah. Kadang-kadang aliran ini bisa saja dinilai positif dan negatif. Positif jika dapat bergerak dalam bidang ekonomi, sosial dan politik serta benar-benar fokus dan maju dibidang kajiannya dan bisa negatif bila dilihat sebagai sebuah gerakan mandiri yang tampak menantang dunia. Aliran-aliran teologi modern saat ini antara lain:

1. Wahhabiyyah

2. Bahaiyyah

3. Qadiyaniyyah

\section{Perkembangan Teologi Islam di Dunia Modern}

Ada kekhawatiran besar di kalangan umat Islam untuk "memerintahkan yang baik dan melarang yang jahat," seperti yang sering diperintahkan Al-Quran. Tugas ini membutuhkan disiplin sosial, hukum, politik dan budaya di bawah Syariah. Tetapi ketika Syariah sendiri hanya dapat diterapkan secara selektif dalam konteks hukum sekuler Kanada dan Amerika Serikat, akan muncul faktor-faktor Islam dan Islamisasi lainnya yang dapat mempertahankan rasa yang diperlukan akan identitas komunal, dan keamanan. Ibn Rushd, tidak seperti banyak filsuf lain, memiliki pengalaman luas tentang kondisi manusia sebagai hakim. Dia percaya bahwa agama adalah dimensi fundamental dari kehidupan manusia, dengan demikian tentu sangat penting bagi kehidupan negara. Jauh dari memberitakan "kebenaran ganda," Ibn Rushd menganggap wahyu sebagai alasan untuk melengkapi dan sama-sama esensial untuk kehidupan yang memuaskan. Nasihatnya yang terkenal untuk "memilih agama terbaik saat itu" tidak harus ditafsirkan sebagai relativisme yang sembrono tetapi pengamatan fungsional yang cerdas dan fungsional. Bisa diartikan sebagai bentuk terbaik dari satu agama. Ibn Rushd lebih merupakan seorang teolog daripada pemikir Aristotelian sebelumnya, ia menempatkan agama dan alasan di dataran tertinggi yang sama dari upaya manusia, sedangkan Al-Farabi menempatkan filsafat di atas. Bagi lbn Rushd, pemikir tingkat lanjut harus terus berhubungan dengan kehidupan umat Islam biasa yang beragama sederhana. Dia melihatnya sebagai salah satu tugas filsuf untuk memberikan kritik teologis moral yang berkelanjutan tentang kehidupan kontemporer dalam terang akal dan tulisan suci. Salah satu alasan paling penting untuk berkembangnya pemikiran religius Muslim di dunia modern karena semakin banyak kebebasan berekspresi yang ditemukan. Meskipun ada banyak di negara-negara Muslim tradisional dan masyarakat yang telah lama mengakui perlunya memperbarui dan mencari intelektual independen dalam hal-hal keagamaan, hukuman untuk go public dengan itu kadang-kadang sangat parah. Dengan demikian, pendekatan teologis di dunia modern dalam memahami agama adalah pendekatan yang menekankan bentuk formal simbol-simbol keagamaan, mengklaim sebagai agama yang paling benar, yang lainnya salah sehingga memandang bahwa paham orang lain itu keliru, kafir, sesat, dan murtad. 
Secara historis-sosiologis Islam merupakan bagian dari realitas sosial, sistem pemikiran, dan gerakan yang hidup dalam sejarah. Pada tataran kesejarahan ini Islam tidak lagi terdiri dari doktrin yang pasif-statis, tetapi mewujud dalam institusi dan sistem pemikiran tertentu yang aktif dan dinamis. Oleh karena sifatnya yang dinamis, maka Islam pada saat tertentu mengalami kemajuan, pada saat yang lain bisa mengalami kemunduran. Islam historis telah ditandai dengan kontinuitas intelektual dan spiritual yang menjadi ciri pokok umat Islam.

Karenanya diperlukan membumikan teologi Islam dalam konteks Islam pada negara modern, sehingga bisa menyampaikan mengenai Islam di ruang publik namun tidak menyinggung atau mengancam Agama lain disana, kemungkina besar hal itu melalui dialog antar Agama. Membumikan teologi Islam dalam konteks kehidupan modern memang memerlukan strategi dan metodologi yang akurat. Usaha Arkoun dalam konteks rekonstruksi bangunan pemikiran teologi Islam adalah salah satu strateginya. Sebagai seorang professor di bidang pemikiran Islam, ia memiliki kegelisahan terhadap kondisi pemikiran teologi Islam yang tidak mengalami dinamika dan dialektika pemikiran Islam. la berusaha membongkar bangunan pemikiran teologi Islam secara totalitas. Kritik yang dibawanya adalah kritik epistemologi atau kritik nalar yang memasuki sendisendi paling dalam pemikiran Islam. Dengan kata lain, arkeologi pemikiran Islam menjadi penting untuk ditelaah lebih jauh sebelum melakukan pembongkaran bangunan pemikiran Islam. Arah dari semua konsepsi ini adalah bagaimana membumikan teologi Islam dalam kehidupan modern sehingga ia tetap aktual meskipun terjadi perubahan zaman dan situasi.

Dengan demikian, pendekatan teologis didunia modern dalam memahami agama adalah pendekatan yang menekankan bentuk formal simbol-simbol keagamaan, mengklaim sebagai agama yang paling benar, yang lainnya salah sehingga memandang bahwa paham orang lain itu keliru, kafir, sesat, dan murtad. Karenanya diperlukan membumikan teologi Islam dalam konteks islam di Amerika Utara, sehingga bisa menyampaikan mengani Islam di ruang publik namun tidak menyinggung atau mengancam Agama lain disana, kemungkinan besar hal itu melalui dialog antar Agama.

Sebagaimana disebutkan di muka bahwa perbedaan historisitas pemahaman antara masa lalu dengan masa sekarang dan yang akan datang memungkinkan terjadinya perbedaan produk pemikiran. Kendati demikian bukan berarti khazanah masa lalu itu tidak ada relevansinya sama sekali untuk pengembangan pemikiran Islam masa sekarang dan masa depan. Berikut ini uraian beberapa contoh yang membuktikan bahwa tidak sedikit khazanah pemikiran masa lalu yang masih relevan untuk menjawab problem dan tantangan kontemporer. Pemecahan problem kebekuan pemikiran Islam kontemporer mustahil dapat dilakukan jika tidak melihat problem pemikiran Filsafat Islam klasik. Secara metodologis filsafat Islam klasik telah meletakkan dasar-dasar bagaimana meramu sumber ajaran Islam dengan tradisi pemikiran lain, misalnya Hellenisme Yunani. Aspek positif dari Filsafat Islam klasik yang relevan untuk menjawab tantangan kontemporer adalah kebebasan berfikir dan sikap terbuka terhadap pemikiran lain. Sebagai misal Ibn Rusyd adalah seorang filosof yang piawai dalam meramu ajaran Islam dengan filsafat Yunani. Pemikiranpemikirannya yang rasional tidak menjadikannya berpaling dari Tuhan. Ibn Rusyd dan filosof muslim lainnya memberi nuansa filsafat Yunani itu dengan nilai dasar Islam.

Masdar Farid Mas'udi menjelaskan bahwa dalam konteks kekinian keterbukaan itu diwujudkan dengan cara mempelajari filsafat, ilmu pengetahuan dan teknologi modern yang berkembang di Barat, atau dari mana pun asalnya. Kebekuan dan ortodoksi pemikiran Islam akan segera mencair manakala umat Islam tidak keberatan menengok kepada tradisi-tradisi. Pengaruh nyata dari Filsafat dalam Islam adalah munculnya pemikiran Kalam yang rasional. Kalam merupakan bentuk lain dari usaha umat Islam klasik mempertahankan kemurnian ajaran Islam dari serangan tradisi pemikiran lain. Apa yang dilakukan Mu'tazilah cukup membuktikan bahwa Islam mampu menghancurkan alam pikiran asing yang merusak ajaran Islam, sekaligus menunjukkan orisinalitas rasionalisme Islam. Hanya saja sikap rasional Mu'tazilah muncul kepermukaan karena dialektika 
antara elit muslim di Baghdad. Problem yang menjadi perhatian Mu'tazilah hanya dalam tataran ide atau pemikiran, sehingga teologi yang diajarkan tidak menyentuh problem masyarakat bawah secara langsung. Sikap rasional-teologis sebagaimana yang dikemukakan oleh Mu'tazilah adalah untuk memecahkan problem kekinian, dan itu merupakan suatu keharusan. Hanya saja, teologi yang layak dikembangkan saat ini adalah "teologi kerakyatan", bukan "teologi elitis". Teologi kerakyatan yang dimaksud adalah bagaimana Islam mampu mendorong kepada umatnya untuk memecahkan problem kemiskinan ekonomi, keterbelakangan pendidikan dan keterasingan rakyat dari politik.

Pengaruh filsafat Islam dan rasionalisme Kalam menurut M. Atho Mudzhar juga merambah dalam pemikiran hukum Islam atau figh. Dalam khazanah pemikiran Hukum Islam dikenal adanya ijtihad (usaha secara sungguh-sungguh untuk menggali ajaran Islam dari sumbernya). ljtihad merupakan wujud kegiatan akal dan menjadi prinsip gerak dalam Islam. litihad telah dicontohkan para sahabat, dan ulama klasik seperti Umar ibn Khattab, Anas Ibn Maliki, Muhammad ibn Idris Syafii, Ibn Hambal dan masih banyak lagi lainnya. Ilmu pengetahuan dan teknologi di samping memberi manfaat yang banyak bagi kehidupan juga memunculkan problem baru di masyarakat. Misalnya seorang wanita berkat kecerdasannya dan penguasaannya dalam ilmu tertentu berpeluang menjadi pemimpin nasional. Sementara pada masa Nabi tidak terjadi demikian. Oleh karena itu umat Islam saat ini harus melakukan ijtihad baru tentang kepemimpinan politik, perburuhan, perbankan dan lain sebagainya. Agar dapat melakukan ijtihad diperlukan keberanian-keberanian yang mungkin saja bertentangan dengan produk pemikiran hukum lama. Di samping itu juga harus memahami situasi sosio-kultural dan politik yang sedang berlangsung.

Nasution adalah seorang pemikir rasional yang membawa pengaruh besar dalam khazanah pemikiran Islam di Indonesia. Beliau telah mengupayakan dengan kemampuan intelektualnya agar teologi yang sebelumnya dianggap sebagai ilmu langit untuk dibumikan dan diaktualisasikan dalam kehidupan sosial. Dalam kaitan ini, Mohammad Arkoun mengatakan bahwa seharusnya pemikiran teologis bergerak tidak hanya dalam bentuk vertikal: normatif-doktrinal-religius, tetapi juga bergerak secara horizontal: historis-empiris-sosiologis.

Selanjutnya, Nasution (1994) juga memandang teologi rasional sesuai untuk masyarakat modern karena ia memiliki konsekuensi erat dengan perbuatan manusia dalam hidup keseharian. Selain itu Nasution juga berpandangan tentang kehidupan sosial kemasyarakatan sebagai implikasi pemahaman teologi yang telah memasyarakat. Pembahasan mencakup relevansi dan aktualisasi teologi dalam aspek pendidikan, politik, budaya, dan sosial kemasyarakatan.

Penafsiran agama dalam konteks modern dan penyesuaian nilai agama dengan budaya modern sesungguhnya menjadi agenda umat Islam sepanjang waktu. Kuntowijoyo (1995) mengatakan bahwa umat Islam dengan kesadaran normatifnya akan menjadi sebuah kelompok yang terus menerus dimotivasi oleh kesadaran subjektifnya untuk membela dan memperjuangkan keadilan sosial dan ekonomi.

Karena ajaran agama yang bersifat absolut sangat sedikit dan yang banyak adalah ajaran agama yang tidak bersifat absolut, maka tidaklah perlu dikhawatirkan bahwa agama akan menghambat perkembangan kebudayaan. Ajaran dasar itu, sebagaimana pada masa lampau, akan turut berkembang menurut perkembangan zaman. Agama tidak mesti menjadi penghambat bagi perkembangan ilmu pengetahuan, teknologi, kebudayaan dan pembangunan pada umumnya. Apa yang disampaikan tersebut tampaknya memang menjadi pandangan umum tokoh pembaharuan Islam modern di berbagai belahan dunia, termasuk Indonesia. Umumnya tokoh-tokoh Islam modern berpandangan bahwa budaya diizinkan berkembang sejauh tidak bertentangan dengan ajaran dasar agama. Hal ini semakin niscaya pada saat kehidupan manusia dihadapkan pada kondisi cukup kompleks dalam berbagai bidang sehingga menimbulkan berbagai persoalan yang harus diselesaikan dengan logika. Selanjutnya hal inilah yang kemudian berkembang menjadi budaya masyarakat. 
Berbicara tentang corak pemikiran kalam modern, tentu saja akan sangat bervariasi, sesuai dengan situasi dan kondisi masyarakatnya. Pada masyarakat yang maju, barangkali pemikiran kalamnya cenderung ke arah rasional, yang mengharuskan segala sesuatu dapat bersifat logis dan empiris. Banyak pendapat-pendapat yang timbul pada saat pemikiran kalam klasik dan pendapat inilah sebagai pijak dasar pikiran-pikiran teologi klasik, seperti khawarij, murjiah, jabariyah, qadariyah, dan aliran ini berkembang dengan berbagai bentuknya tetapi masih memperdebatkan prinsip-prinsip dasar dalam Islam seperti Asy"eariyah, Mu"tazilah, Maturidiyyah Samarkand dan Maturidiyah Bazdawi, aliran-aliran pemikiran klasik memiliki kecenderungan berbeda, sebagian masih ada yang berpikir kepada sandaran wahyu dan ada juga yang lebih cenderung menyandarkan pemikirannya tersebut kepada akal. Hal ini kemudian berkembang dari waktu ke waktu dan senantiasa mengalami pergeseran.

\section{KESIMPULAN}

Secara teologis Islam merupakan sistem nilai yang bersifat ilahiyah, tetapi dari sudut sosiologis, ia merupakan fenomena peradaban, kultural dan realitas sosial dalam kehidupan manusia, ia tidak dapat menghindarkan diri dari kenyataan sosial lain, yaitu perubahan apalagi, di lihat dari pandangan ajaran Islam sendiri, perubahan adalah sunnatullah yang merupakan salah satu sifat asasi manusia dan alam raya secara keseluruhan.

Pergumulan antara doktrin ajaran Islam dengan sejarah yang terus bergulir membuahkan produk pemikiran keagamaan tertentu. Secara sosiologis pemikiran keagamaan Islam akan terus mengalami perkembangan sesuai dengan perubahan sejarah dan problem yang mengitarinya, seperti yang tampak dalam pemikiran Islam klasik. Meskipun berbeda latar belakang sejarahnya. Pemikiran Islam klasik merupakan warisan yang sangat berharga untuk membantu memecahkan problem kontemporer yang semakin akut. Oleh karena itu, mempelajari dan mengambil khazanah pemikiran Islam klasik harus dilakukan dalam dunia yang sangat modern sekalipun. Tetapi pengambilan warisan itu harus tetap disertai dengan sikap kritis-analitik.

Karenanya diperlukan membumikan teologi islam dalam konteks islam pada negara modern, sehingga bisa menyampaikan mengani islam di ruang publik namun tidak menyinggung atau mengancam Agama lain disana, kemungkina besar hal itu melalui dialog antar Agama. Membumikan teologi Islam dalam konteks kehidupan modern memang memerlukan strategi dan metodologi yang akurat.

\section{REKOMENDASI}

Rekomendasi dari penelitian ini adalah sebaiknya diteliti mengenai cara dapat berupa strategi dan metodologi untuk membumikan teologi Islam dalam konteks kehidupan modern.

\section{UCAPAN TERIMAKASIH}

Penyusunan penelitian ini tidak lepas dari bantuan semua pihak, oleh karena itu, penulis merasa sangat berhutang budi kepada semua pihak, sehingga pada kesempatan ini penulis mengucapkan terima kasih kepada pihak-pihak yang telah memberikan semangat dan bantuan, baik material maupun secara spiritual. Ucapan terima kasih yang sedalam-dalam nya secara khusus penulis sampaikan kepada :

1. Bapak Dr. H. Tedi Priatna, M.Ag yang telah banyak mencurahkan tenaga, pikiran, ilmu yang bermanfaat, serta waktunya guna membimbing penulis dalam menyelesaikan penelitian ini.

2. Bapak. Dr. H. Hasbiyallah, M.Ag yang telah banyak meluangkan waktu untuk memberikan bimbingan, arahan, pikiran serta banyak memberikan ilmu yang bermanfaat, sehingga penulis dalam menyelesaikan penelitian ini. 


\section{DAFTAR PUSTAKA}

Abbas. (2005). Paradigma dan Corak Pemikiran Teologi Islam Klasik dan Modern, Shautut Tarbiyah, Ed. Ke-32 Th. XXI, Mei 2015.

Abdullah, M. A. (1995). Falsafah Kalam di Era Postmodernisme. Yogyakarta: Pustaka Pelajar.

Amin, F. (2012). Ilmu Kalam Sebuah Tawaran Pergeseran Paradigma Pengkajian Teologi Islam, Pontianak: STAIN Pontianak Press.

Anshary, T. (2015). Dari Puncak Bagdad: Sejarah Dunia Versi Islam, terj. Yuliani Liputo, Jakarta: Zaman.

Arkoun, M. (1994). Metode Kritik Akal Islam" al-Fikr al-Islam: Naqd wa ljtihad, terj. Ulil Abshar Abdalla dalam Jurnal Ulumul Quran 5, No. 5.

Bagus, L. (1996). Kamus Filsafat. Jakarta: Gramedia.

Hanafi, A. (1989). Pengantar Teologi Islam. cet 3 Jakarta: Pustaka al-Husna.

Nasution, H. (1994). Islam Rasional Gagasan dan Pemikiran Prof. Dr. Harun Nasution. Bandung: Mizan.

Razak, A., \& Anwar, R. (2006). Ilmu Kalam. Pustaka Setia: Bandung.

Kuntowijoyo. (1995). Paradigma Islam, Bandung: Mizan. 
